\title{
Fc-Independent Protection from SARS-CoV-2 Infection by Recombinant Human Monoclonal Antibodies
}

\author{
Tal Noy-Porat ${ }^{1}$, Avishay Edri ${ }^{2}$, Ron Alcalay ${ }^{1}{ }^{10}$, Efi Makdasi $^{1}$, David Gur ${ }^{1}$, Moshe Aftalion ${ }^{1}$, Yentl Evgy ${ }^{1}$, \\ Adi Beth-Din 1(D, Yinon Levy 1, Eyal Epstein 1, Olga Radinsky 2, Ayelet Zauberman 1(D, Shirley Lazar ${ }^{1}$, \\ Shmuel Yitzhaki ${ }^{1}$, Hadar Marcus ${ }^{1}$, Angel Porgador ${ }^{2}$, Ronit Rosenfeld ${ }^{1, *}$ and Ohad Mazor ${ }^{1, * \mathbb{D}}$ \\ 1 Israel Institute for Biological Research, Ness-Ziona 7404800, Israel; taln@iibr.gov.il (T.N.-P.); \\ rona@iibr.gov.il (R.A.); Efim@iibr.gov.il (E.M.); gurd@iibr.gov.il (D.G.); moshea@iibr.gov.il (M.A.); \\ yentle@iibr.gov.il (Y.E.); adib@iibr.gov.il (A.B.-D.); yinonl@iibr.gov.il (Y.L.); eyale@iibr.gov.il (E.E.); \\ ayeletz@iibr.gov.il (A.Z.); Shirleyl@iibr.gov.il (S.L.); shmuely@iibr.gov.il (S.Y.); hadarm@iibr.gov.il (H.M.) \\ 2 The Shraga Segal Department of Microbiology, Immunology, and Genetics, Faculty of Health Sciences, \\ Ben-Gurion University of the Negev, Beer Sheva 8410501, Israel; avishayedri@gmail.com (A.E.); \\ kisterev@post.bgu.ac.il (O.R.); angel@bgu.ac.il (A.P.) \\ * Correspondence: ronitr@iibr.gov.il (R.R.); ohadm@iibr.gov.il (O.M.)
}

Citation: Noy-Porat, T.; Edri, A.; Alcalay, R.; Makdasi, E.; Gur, D.; Aftalion, M.; Evgy, Y.; Beth-Din, A.; Levy, Y.; Epstein, E.; et al. Fc-Independent Protection from SARS-CoV-2 Infection by Recombinant Human Monoclonal Antibodies. Antibodies 2021, 10, 45. https://doi.org/10.3390/ antib10040045

Academic Editors: Luis MartinezSobrido and James J. Kobie

Received: 16 September 2021 Accepted: 2 November 2021 Published: 8 November 2021

Publisher's Note: MDPI stays neutral with regard to jurisdictional claims in published maps and institutional affiliations.

Copyright: (c) 2021 by the authors. Licensee MDPI, Basel, Switzerland. This article is an open access article distributed under the terms and conditions of the Creative Commons Attribution (CC BY) license (https:/ / creativecommons.org/licenses/by/ $4.0 /)$.

\begin{abstract}
The use of passively-administered neutralizing antibodies is a promising approach for the prevention and treatment of SARS-CoV-2 infection. Antibody-mediated protection may involve immune system recruitment through Fc-dependent activation of effector cells and the complement system. However, the role of Fc-mediated functions in the efficacious in-vivo neutralization of SARS-CoV-2 is not yet clear, and it is of high importance to delineate the role this process plays in antibody-mediated protection. Toward this aim, we have chosen two highly potent SARS-CoV-2 neutralizing human monoclonal antibodies, MD65 and BLN1 that target distinct domains of the spike (RBD and NTD, respectively). The Fc of these antibodies was engineered to include the triple mutation N297G/S298G/T299A that eliminates glycosylation and the binding to Fc $\gamma$ R and to the complement system activator C1q. As expected, the virus neutralization activity (in-vitro) of the engineered antibodies was retained. To study the role of Fc-mediated functions, the protective activity of these antibodies was tested against lethal SARS-CoV-2 infection of K18-hACE2 transgenic mice, when treatment was initiated either before or two days post-exposure. Antibody treatment with both Fc-variants similarly rescued the mice from death reduced viral load and prevented signs of morbidity. Taken together, this work provides important insight regarding the contribution of Fc-effector functions in MD65 and BLN1 antibody-mediated protection, which should aid in the future design of effective antibody-based therapies.
\end{abstract}

Keywords: monoclonal antibodies (mAbs); SARS-CoV-2; fragment crystallizable (Fc); a-glycosylated; K18-hACE2

\section{Introduction}

The ongoing COVID-19 pandemic caused by the severe acute respiratory syndrome coronavirus 2 (SARS-CoV-2) imposed a massive public health and economic crisis and continues to spread globally. Despite the onset of mass vaccination campaigns, the pandemic still exhibits unprecedented morbidity and mortality, highlighting the need for additional effective therapeutics. Human monoclonal antibodies (mAbs), specifically targeting viral surface proteins, have increasingly demonstrated prophylactic and therapeutic efficacy against various viruses including HIV, Ebola, the pathogenic beta-coronaviruses MERS-CoV and SARS-CoV and more recently for SARS-CoV-2 [1-6].

In-vitro antibody-mediated viral neutralization is associated with steric interference with surface epitopes that are essential for virus entry into cells (as in the case of antibodies targeting the receptor-binding domain), membrane fusion, budding and more [7]. However, 
in-vivo antibody-mediated protection may further involve the immune system through Fc-dependent activation of effector cells and the complement system [8-10]. The interplay between these two mechanisms and their individual contribution for effective viral neutralization is pathogen- and antibody-dependent. Indeed, while several studies demonstrated Fc-dependent activity for the neutralization of HIV, influenza and Ebola [11-14], other studies argued the opposite [15]. It should be noted that for moderate or non-neutralizing antibodies in-vitro, efficient Fc-activation of the immune system could augment and sometimes even be crucial for effective in-vivo protection $[12,13]$. On the other hand, extensive activation of the immune system might also lead to antibody-dependent enhancement (ADE) or other unwanted pathologies. Thus, it is essential to delineate the specific role and impact of antibody-based passive protection in the course of the disease and to design the Fc-mediated activity accordingly.

The use of passively-administered neutralizing antibodies is a promising approach for the prevention and treatment of SARS-CoV-2 infection [16,17]. Over the past year, many neutralizing antibodies were isolated, mainly targeting the spike protein and more specifically, its receptor-binding domain (RBD) and N-terminal domain (NTD) [4,18-23]. Despite this body of work, the role of Fc-mediated functions in the efficacious in-vivo neutralization of SARS-CoV-2, is not yet clear and only a limited number of studies have addressed this question so far. It was recently demonstrated that by enhancing the functionality of the Fc, the in-vivo activity of a partially-neutralizing antibody, resulted in increased pathology and enhanced viral replication rather than improving its therapeutic value [24]. On the other hand, in another set of studies, loss-of-function mutations were introduced into the Fc-region of SARS-CoV-2 neutralizing antibodies and their protective activity in infected animals was evaluated, both as a prophylactic treatment and after infection. It was demonstrated that when given prophylactically, the protective activity of the mutated antibodies was minorly affected [25-27]. However, delaying the treatment, even for a short period (2-24 h post infection) markedly reduced viral clearance and the therapeutic effect conferred by these Fc-null antibodies [26-28]. The results of these studies may imply that once virus replication has begun, direct antibody neutralization is insufficient and other mechanisms that are based on Fc-activation are needed. Conversely, it can be argued that antibodies with superior neutralization activity, may be able to exert their direct activity even at late time points post infection, thus making Fc-dependent functions redundant.

As anti-SARS-CoV-2 antibody-based therapy is intended to treat COVID-19 patients or to be given prophylactically to immunocompromised populations, it is highly important to further investigate the Fc's role in antibody-mediated protection against SARS-CoV-2 infection. Therefore, the role played by Fc activation will be a major influencing factor in therapeutic antibody design [29].

We have recently isolated a panel of SARS-CoV-2 neutralizing monoclonal antibodies from blood samples of severe COVID-19 patients [22]. Transgenic K18-hACE2 mice, infected with lethal doses of SARS-CoV-2, were fully protected by these antibodies, even when administered as late as three days post-infection [4], demonstrating the high potency of these antibodies. Thus, we aimed to use these antibodies in order to delineate the role of Fc activation in the protection against SARS-CoV-2 infection.

\section{Materials and Methods}

\subsection{Expression of Proteins and Antibodies}

The previously developed MD65 (IgG1) monoclonal antibody (mAb), harboring the "YTE" Fc mutations for increased half-life [4], was further engineered to obtain an aglycosylated (AG) Fc format (MD65-AG). For that matter, additional three mutations were inserted into the Fc sequence, aiming at disrupting the N-linked glycosylation motif Asn-XSer/Thr (N297G/S298G/T299A). The presence of the desired mutations was confirmed by sequencing and the integrity and purity of the antibody were analyzed using SDS-PAGE. ExpiCHO-S cells (Cat No. A29127, Thermoscientific, Rochford, IL, USA) were cultured at $37{ }^{\circ} \mathrm{C}, 5 \% \mathrm{CO}_{2}$ at $95 \%$ air atmosphere and used for expression of the recombinant 
antibodies, which were then purified using HiTrap Protein-A column (GE healthcare, Madison, WI, USA). The SARS-CoV-2 spike (S) stabilized soluble ectodomain and S1 subunit was produced as previously described 22 .

\subsection{ELISA}

Direct ELISA was performed against the SARS-CoV-2 spike [30]. Maxisorp 96-well microtiter plates (Nunc, Roskilde, Denmark) were coated overnight with $1 \mu \mathrm{g} / \mathrm{mL}$ of spike in $\mathrm{NaHCO}_{3}$ buffer (50 mM, pH 9.6), washed, and blocked with PBST (Phosphate buffer saline, $2 \%$ BSA, $0.05 \%$ Tween 20 ) at room temperature for $1 \mathrm{~h}$. The secondary antibodies: AP-conjugated Donkey anti-human IgG (Jackson ImmunoResearch, Baltimore, PA, USA, Cat\# 709-055-149, lot 130049) or AP-conjugated Donkey anti-mouse IgG (H + L) minimal cross (Jackson ImmunoResearch, USA, Cat\# 715-055-150, lot 142717) were applied, followed by the addition of PNPP substrate (Cat No. N1891, Sigma, Rehovot, Israel).

\subsection{Binding to Recombinant Fc $\gamma$ Rs}

Binding to Fc $\gamma$ Rs was tested using ELISA. CD16 (CatNo. 4325-FC-050, R\&D Systems, Minneapolis, MN, USA) and CD64 (Cat No. 10256-H08S, Sino Biological, Beijing, China) were used to coat 96-well plates at $2 \mu \mathrm{g} / \mathrm{mL}$. For CD16, the plate was incubated with antibodies MD65 and MD65-AG starting at $100 \mu \mathrm{g} / \mathrm{mL}$ with 2-fold serial dilutions. For CD64, antibodies were used starting at $10 \mu \mathrm{g} / \mathrm{mL}$ with serial dilutions. MD65-Fab, at the same concentrations, was used as the negative control. Detection was carried out as described above. Binding to CD32 was tested using biolayer interferometry (BLI) as previously described [31]. Sensors were loaded with CD32 $(10 \mu \mathrm{g} / \mathrm{mL})$, followed by a wash, and then incubated with antibodies MD65 or MD65-AG. MD65-Fab was used as the negative control.

\subsection{Biolayer Interferometry Assays \\ 2.4.1. Complement Binding}

Binding to the complement cascade was evaluated through measurement of antibodies binding to $\mathrm{C} 1 \mathrm{q}$ protein, which represent the first step in the complement activation. Binding assays were carried out using the Octet system (Version 8.1, 2015, ForteBio, Fremont, CA, USA) that measures biolayer interferometry (BLI). All steps were performed at $30^{\circ} \mathrm{C}$ with shaking at $1500 \mathrm{rpm}$ in a black 96-well plate containing $200 \mu \mathrm{L}$ solution in each well. Fab2G sensors were loaded with MD65 mAb or MD65-AG at $10 \mu \mathrm{g} / \mathrm{mL}$, followed by a wash. The sensors were then incubated with C1q native protein (250 nM, Cat No. C0010-10D, US Biologicals, Salem, MA, USA) for $180 \mathrm{~s}$ and then transferred to buffer-containing wells for another $180 \mathrm{~s}$. Binding was measured as changes over time in light interference, after subtraction of parallel measurements from a sensor loaded with MD65-Fab as the negative control.

\subsubsection{Affinity to Human FcRn}

For the evaluation of MD65-AG affinity to human FcRn, anti-Fab-coated sensors were loaded with the antibody $(30 \mu \mathrm{g} / \mathrm{mL})$, to reach a $2.5 \mathrm{~nm}$ wavelength shift, and then washed. Sensors were then incubated with different concentrations of FcRn (Sino Biological, No. CT009-H08H; ranging from 75 to $300 \mathrm{nM}$ ) in $\mathrm{pH}$ 6.0, for $60 \mathrm{~s}$ (association phase) and transferred to buffer-containing wells for an additional $60 \mathrm{~s}$ (dissociation phase). Binding and dissociation were measured as changes over time in light interference after subtraction of parallel measurements from unloaded biosensors. Sensorgrams were fitted with a 1:1 binding model using the Octet data analysis software 8.1 (Fortebio, USA, 2015).

\subsection{CD107a Degranulation Assay}

Cell culture plates were pre-coated with SARS-CoV-2 spike antigen (in Phosphate buffer saline; PBS) and an inert control protein of similar molecular weight, in reciprocal concentrations. Total protein concentration was $2 \mu \mathrm{g} / \mathrm{mL}$ throughout the gradient while 
relative part of each protein varied (0:100, 1:99, 2:98, 4:96, 8:92, 16:84, 32:68, 100:0); Coating performed at $4{ }^{\circ} \mathrm{C}$ overnight. Plates were then washed twice with PBS and the tested mAbs were introduced in $2 \mu \mathrm{g} / \mathrm{mL}$ for $1-\mathrm{h}$ incubation in $4{ }^{\circ} \mathrm{C}$ for $\mathrm{Ag}-\mathrm{mAb}$ complex formation. Plates were then washed twice with PBS and primary NK cells ( $\mathrm{pNK}$ ) were introduced at a concentration of $2.5 \times 10^{5}$ cells $/ \mathrm{mL}$ in $200 \mu \mathrm{L} /$ well $\left(5 \times 10^{4}\right.$ cell/well $)$ in complete SCGM media diluted 1:10 with complete RMPI media, final assay media contained $30 \mathrm{u} / \mathrm{mL}$ of a recombinant human IL-2 and $4 \mu \mathrm{g} / \mathrm{mL}$ allophycocyanin conjugated anti-CD107a. Cells were incubated at $37{ }^{\circ} \mathrm{C}$, in a $5 \% \mathrm{CO}_{2}$ incubator for $4.5 \mathrm{~h}$. plates were then centrifuged at $300 \times g$ for $5 \mathrm{~min}$, assay media was collected, and cells were stained using $4 \mu \mathrm{g} / \mathrm{mL}$ allophycocyanin conjugated anti-CD107a, and DAPI viability dye. Cell analysis was performed using CytoFLEX V5-B5-R3 Flow Cytometer (Beckman Coulter, Indianapolis, IN, USA).

\subsection{FC r Receptor Potency Assay}

Cell culture plates were pre-coated with SARS-CoV-2 spike antigen in a concentration of $2 \mu \mathrm{g} / \mathrm{mL}$ at $4{ }^{\circ} \mathrm{C}$, overnight. Plates were then washed twice with PBS and tested mAbs were serially diluted and introduced to wells for Ag-mAb complex formation. Plates were incubated for $1 \mathrm{~h}$ in $4{ }^{\circ} \mathrm{C}$, washed twice with PBS and human FC $\gamma$ receptor (Fc $\gamma$ RIIIa, $\mathrm{Fc}_{c} \gamma \mathrm{RIIa}$ and $\mathrm{Fc}_{\mathrm{c}} \gamma \mathrm{RI}$ ) expressing BW5147 thymoma cells were introduced to the Ag-mAb presenting wells during $16 \mathrm{~h}$ incubation [32]. Plates were then centrifuged at $300 \times g$ for $5 \mathrm{~min}$, assay media was collected and murine IL-2 was quantified by ELISA. The supernatant of activated cells was collected and specific cytokines were quantified by ELISA. 96-well plates were pre-coated (in $0.1 \mathrm{M}, \mathrm{Na}_{2} \mathrm{HPO} ; \mathrm{pH} 9.0$ ) at $4{ }^{\circ} \mathrm{C}$ overnight with $70 \mu \mathrm{L} /$ well of $1 \mu \mathrm{g} / \mathrm{mL}$ of a relevant capture mAb: purified anti-human IFN- $\gamma$ (Clone: NIB42, BioLegend, San Diego, CA, USA); purified anti-human TNF- $\alpha$ (Clone: MAb1, BioLegend), or purified anti-mouse IL-2 (Clone: JES6-1A12, BioLegend). Plates were then incubated with blocking solution containing 10\% FBS in PBST (0.05\% Tween-20), washed and incubated with the collected supernatant for $2 \mathrm{~h}$, followed by the addition of relevant detection mAbs: biotin anti-human IFN- $\gamma$ (Cat\# 502503 Clone: 4S.B3, BioLegend); biotin anti-human TNF- $\alpha$ (Clone: MP6-XT22, BioLegend); or biotin anti-mouse IL-2 (Clone: JES65H4, BioLegend) SA-HRP (Jackson immunoresearch, Baltimore, PA USA) and TMB (Dako, Copenhagen, Denmark) used for detection of mIL-2.

\subsection{Plaque Reduction Neutralization Test (PRNT)}

Plaque reduction neutralization test (PRNT) performed essentially as described [33] using SARS-CoV-2 (GISAID accession EPI_ISL_406862) strain that was kindly provided by Bundeswehr Institute of Microbiology, Munich, Germany and Vero E6 (ATCC ${ }^{\circledR}$ CRL1586TM), obtained from the American Type Culture Collection. Half-maximum inhibitory concentration (IC50) was defined as $\mathrm{mAb}$ concentration at which the plaque number was reduced by $50 \%$, compared to the plaque number of the control (in the absence of $\mathrm{mAb}$ ).

\subsection{Animal Experiments}

Treatment of animals was in accordance with regulations outlined in the U.S. Department of Agriculture (USDA) Animal Welfare Act and the conditions specified in the Guide for Care and Use of Laboratory Animals (National Institute of Health, 2011). Animal studies were approved by the local ethical committee on animal experiments (protocol number M-51-20). Female K18-hACE2 transgenic (B6.Cg-Tg(K18 ACE2)2Prlmn/J HEMI) were maintained at $20-22{ }^{\circ} \mathrm{C}$ and relative humidity of $50 \pm 10 \%$ on a $12 \mathrm{~h}$ light/dark cycle, fed with commercial rodent chow (Koffolk Inc., Petach Tikva, Israel) and provided with tap water ad libitum. The age of the animals at the time of the onset of experiments ranged between 9-14 weeks old. All animal experiments involving SARS-CoV-2 were conducted in a BSL3 facility. Infection experiments were carried out using SARS-CoV-2, isolate Human 2019-nCoV ex China strain BavPat1/2020 that was kindly provided by Prof. Dr. Christian Drosten (Charité, Berlin, Germany) through the European Virus Archive-Global (EVAg 
Ref-SKU: 026V-03883). The original viral isolate was quantified by plaque titration assay in Vero E6 cells and stored at $-80{ }^{\circ} \mathrm{C}$ until use. The viral stock DNA sequence and coding capacity were confirmed as recently reported [34]. SARS-CoV-2 BavPat1/2020 virus diluted in PBS supplemented with 2\% FBS (Biological Industries, Beit Haemek, Israel) was used to infect animals by intranasal instillation of anesthetized mice. For mAbs protection evaluation, mice were treated IP either at the time of infection or 2 days post-infection. Control groups were administered with PBS at the indicated times. Bodyweight was monitored daily throughout the follow-up period post-infection. Mice were evaluated once a day for clinical signs of disease and dehydration. Euthanasia was applied only when the animals exhibited irreversible disease symptoms (rigidity, lack of any visible reaction to contact).

\subsection{Measurement of Viral RNA by $q R T-P C R$}

Viral load in lungs of SARS-CoV-2 infected mice was quantified by qRT-PCR and by plaque assay [4]. Lungs were ground in $1.5 \mathrm{~mL}$ of PBS and $200 \mu \mathrm{L}$ was added to LBF lysis buffer. RNA was extracted using RNAdvance Viral Kit on a Biomek i7 automated workstation (Beckman Coulter, Indianapolis, IN, USA), according to the manufacturer's protocol. Each sample was eluted in $50 \mu \mathrm{L}$ of RNase-free water. RT-PCR was performed using the SensiFASTTM Probe Lo-ROX One-Step kit (Bioline, London, UK). Primers and probe sequences, targeting the SARS-CoV-2 E gene, were based on the Berlin protocol published in the WHO recommendation for the detection of SARS-CoV-2 and as described before [4]. The thermal cycling reaction was performed at $48{ }^{\circ} \mathrm{C}$ for $20 \mathrm{~min}$ for reverse transcription, followed by $95{ }^{\circ} \mathrm{C}$ for $2 \mathrm{~min}$, and then 45 cycles of $15 \mathrm{~s}$ at $94{ }^{\circ} \mathrm{C}$; $35 \mathrm{~s}$ at $60^{\circ} \mathrm{C}$ for the E gene amplification. Cycle Threshold $(\mathrm{Ct})$ values were converted to PFU equivalents (PFU Eqv.), according to a calibration curve determined in parallel.

\subsection{Lung Histology}

Lungs were rapidly isolated, fixed in 4\% PBS-buffered formaldehyde at room temperature for one week, followed by routine processing for paraffin embedding. Serial sections, $5 \mu \mathrm{m}$-thick, were cut and selected sections were stained with hematoxylin and eosin (H\&E) and examined by light microscopy. Images were acquired using the Panoramic MIDI II slide scanner (3DHISTEC, Budapest, Hungary).

\section{Results}

\subsection{Construction of Fc-Engineered Antibodies}

Antibody-mediated activation of the Fc-gamma receptor $(\mathrm{Fc} \gamma \mathrm{R})$ plays a major role in viral neutralization in-vivo [7,8]. The human Fc $\gamma \mathrm{RI}$ (CD64) has a higher affinity for both monomeric IgG and immune complexes, whereas Fc $\gamma$ RIIa (CD32) and Fc $\gamma$ RIIIa (CD16) strongly bind to IgG immune complexes [10]. A single point mutation at N297 at the Nlinked glycosylation motif Asn-X-Ser/Thr (N297/S298/T299) was previously reported to eliminate glycosylation and dramatically, but not completely, reduce binding to $\mathrm{Fc} \gamma \mathrm{R}$ and to the complement system activator C1q [35-38]. Maintaining the N-linked glycosylation while introducing double mutations at S298G/T299A was shown to specifically maintain binding to Fc $\gamma$ RII while abolishing binding to all other Fc $\gamma R$ [39]. Fully mutating the N-linked glycosylation motif by insertion of triple mutations at positions 297-299 inhibited this binding as well [39].

To study the role of Fc-mediated activation of immune effector functions in SARSCoV-2 neutralization, we applied the human monoclonal antibody (mAb) MD65, recently reported to potently neutralize SARS-CoV-2 in-vitro [22] and in-vivo [4,40]. Moreover, this antibody was recently found to retain its ability to bind and effectively protect mice against the prevalent viral SARS-CoV-2 mutants, B.1.1.7 and B.1.351 variants [41]. The MD65 antibody backbone includes the triple mutation M252Y/S254T/T256E (YTE) in the Fc region (schematically depicted in Figure 1A) aimed at increasing the antibody affinity towards the human $\mathrm{F} C \mathrm{Rn}$ at acidic $\mathrm{pH}$, therefore, prolonging its serum half-life [32,42,43]. The addition of the YTE triple mutation was previously suggested to hamper the ability 
of the antibody to activate ADCC, although the binding to Fc $\gamma \mathrm{R}$ was not eliminated and ADCC levels remained high [44,45]. In order to diminish its Fc-dependent functions, MD65 was further engineered to include the additional triple mutation N297G/S298G/T299A (MD65-AG, Figure 1A). The engineered antibody was expressed in CHO cells. We first wished to confirm that its potency toward SARS-CoV-2 was retained. Indeed, a comparison of the two versions of the MD65 confirmed that overall, their spike-binding performance is comparable (Figure 1B), exhibiting apparent $\mathrm{KD}$ of $0.4 \mathrm{nM}$ versus $0.5 \mathrm{nM}$, for MD65 and MD65-AG versions, respectively). Similarly, the two MD65 formats were evaluated by plaque reduction neutralization test (PRNT) and were shown to possess equivalent SARS-CoV-2 neutralization potency in-vitro (NT50 of 41 and $38 \mathrm{ng} / \mathrm{mL}$, for MD65 and MD65-AG respectively, Figure 1C).

\section{A}
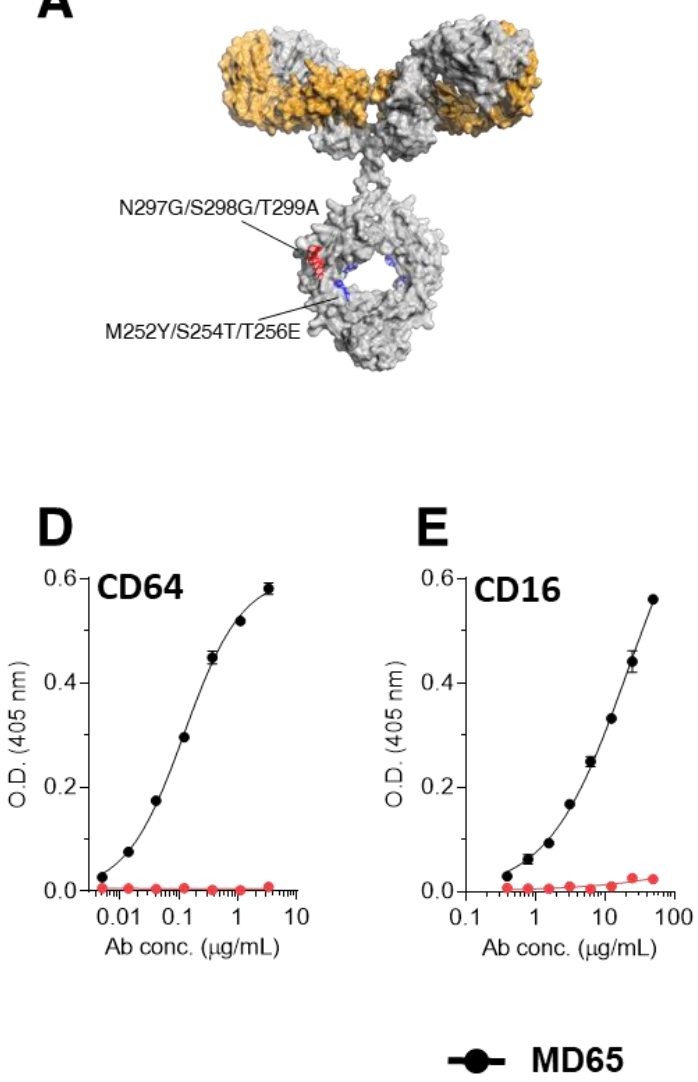
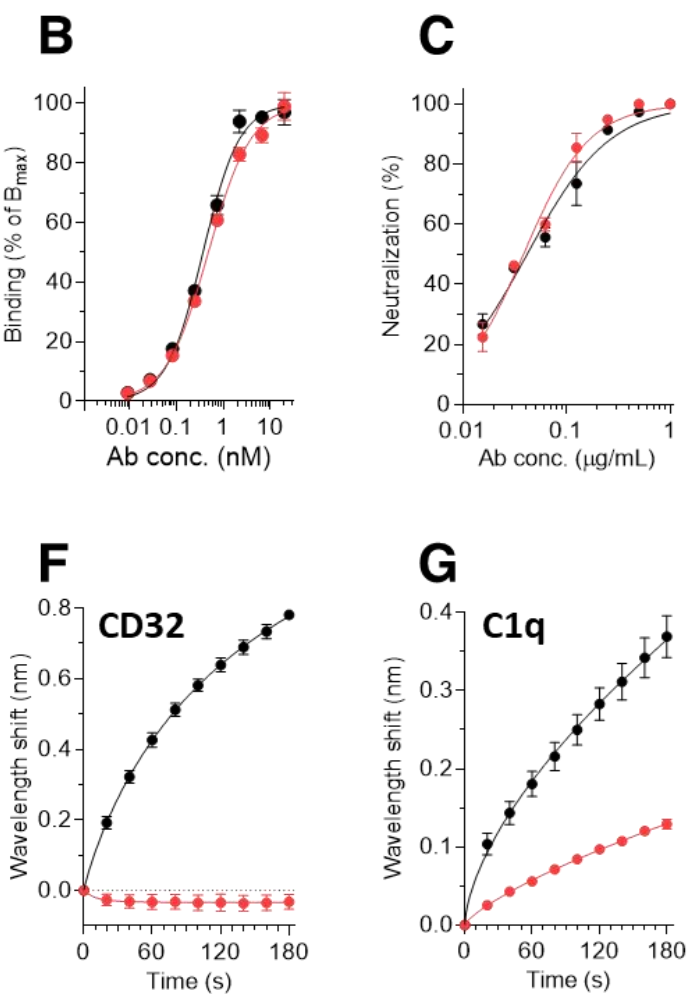

\section{MD65-AG}

Figure 1. Binding characteristics of the MD65 antibody engineered versions. (A) Schematic representation of the mutations inserted into the YTE version (Red) and the AG version (Red and Blue). (B) Binding to immobilized SARS-CoV-2 spike protein, tested by ELISA. (C) in-vitro neutralization of SARS-CoV-2 using plaque reduction neutralization test (PRNT). (D,E) Binding to immobilized CD64 (D) or CD16 (E), evaluated by ELISA. (F) BLI measurements of the binding of each antibody to immobilized CD32. (G) BLI measurements of the binding of C1q to the immobilized antibodies. Values are average \pm SEM of triplicates of a representative experiment $(\mathbf{B}-\mathbf{E})$ or of three independent experiments $(\mathbf{F}, \mathbf{G})$.

We next sought to confirm that the mutated MD65-AG antibody could not interact with the main Fc-mediated effector molecules. To this end, the binding of the antibodies to CD64 was evaluated using ELISA. As expected, MD65 exhibited a dose-dependent binding pattern whereas no binding of the AG variant could be detected in all tested concentrations (Figure 1D). Similarly, while MD65 showed robust binding to immobilized CD16, no interaction was observed with the MD65-AG antibody (Figure 1E). The binding to CD32a was evaluated using biolayer interferometry (BLI), where the receptor was immobilized to the sensor and then reacted with either version of MD65. Indeed, while MD65 induced a significant wavelength shift indicating binding to the receptor, no binding was observed for the MD65-AG antibody (Figure 1F). It was also of interest to determine whether the 
incorporation of these mutations had also affected the antibody's ability to interact with the complement system. Since the complement cascade is initiated by the binding of $\mathrm{C} 1 \mathrm{q}$ to the IgG-antigen immune complex, we evaluated its ability to interact with the MD65 antibody variants. Each antibody was immobilized on a BLI sensor, followed by incubation with a constant concentration of $\mathrm{C} 1 \mathrm{q}$ which upon binding to the antibodies, induce a measurable wavelength shift. It was found that C1q could efficiently bind MD65, whereas its binding to the AG variant was greatly impaired (Figure 1G). Non-linear fitting of the binding curves revealed that the affinity and the extrapolated Bmax values of C1q toward MD65-AG were about 260 and 50 times lower, respectively, when compared to the binding values toward MD65. These results suggest that the MD65-AG has retained only residual binding capability to $\mathrm{C} 1 \mathrm{q}$ and completely lost its ability to bind to the Fc-receptor family.

It has been previously established that a major aspect of the monoclonal antibody therapeutic effect, is based on NK cell mediated antibody-dependent cellular cytotoxicity (ADCC) [7]. Therefore, we have conducted a series of ex vivo functional assays to assess ADCC induced by both MD65 and MD65-AG using enriched primary NK cells (pNK). A model system was tailored to specifically inspect the mAb-pNK cell activation axis (expression of CD107a and secretion of IFN $\gamma$ and TNF $\alpha$ ) [46]. In order to induce Ag-mAb complex formation, tested $\mathrm{mAbs}$ were incubated with a reciprocal concentration gradient of SARS-CoV-2 spike and inert control protein of similar molecular weight, keeping the total protein concentration constant. The membrane-associated CD107a staining assay indicates the extent of the pNK cells' activation and degranulation. As expected, only incubation of pNK cells with spike complexed with MD65 induced elevated cell surface expression of CD107a (Figure 2A). Accordingly, pNK cells secreted significantly less IFN $\gamma$ and TNF $\alpha$ when incubated with MD65-AG complexed with spike as compared to incubation with MD65-spike complex (Figure 2B,C).

To further validate our findings, we assessed the activation potency of both MD65 and MD65-AG that is mediated through Fc $\gamma$ receptors. We have utilized the recently developed cell-based reporter system, designed to quantitate CD16 (Fc $\gamma$ RIIIa), CD32 (Fc $\gamma$ RIIa) and CD64 (Fc $\gamma$ RI) mediated activation potency [47]. Plates were coated with SARS-CoV-2 spike, incubated with increasing concentrations of either MD65 or MD65-AG and washed to remove antibody excess. Reporter cells were then added to the immobilized Ag-mAb complexes and secreted mIL-2 was quantified, as a marker for reporter cell activation. Indeed, a distinct difference in activation potency between tested mAbs was observed, with MD65 inducing significant, dose-dependent levels of activation of CD16 and CD32 Fc $\gamma$ Rs (Figure 2D,E). Similarly, MD65 induced strong activation of CD64 presenting cells, while only marginal activation was caused by MD65-AG complexed with spike (Figure 2F).
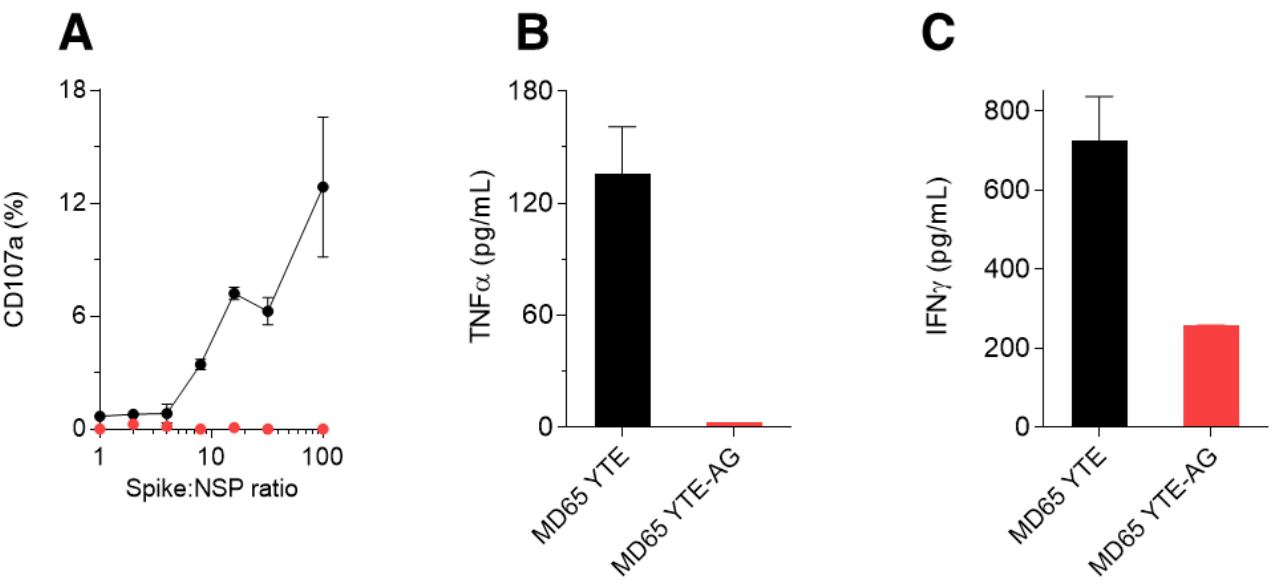

Figure 2. Cont. 

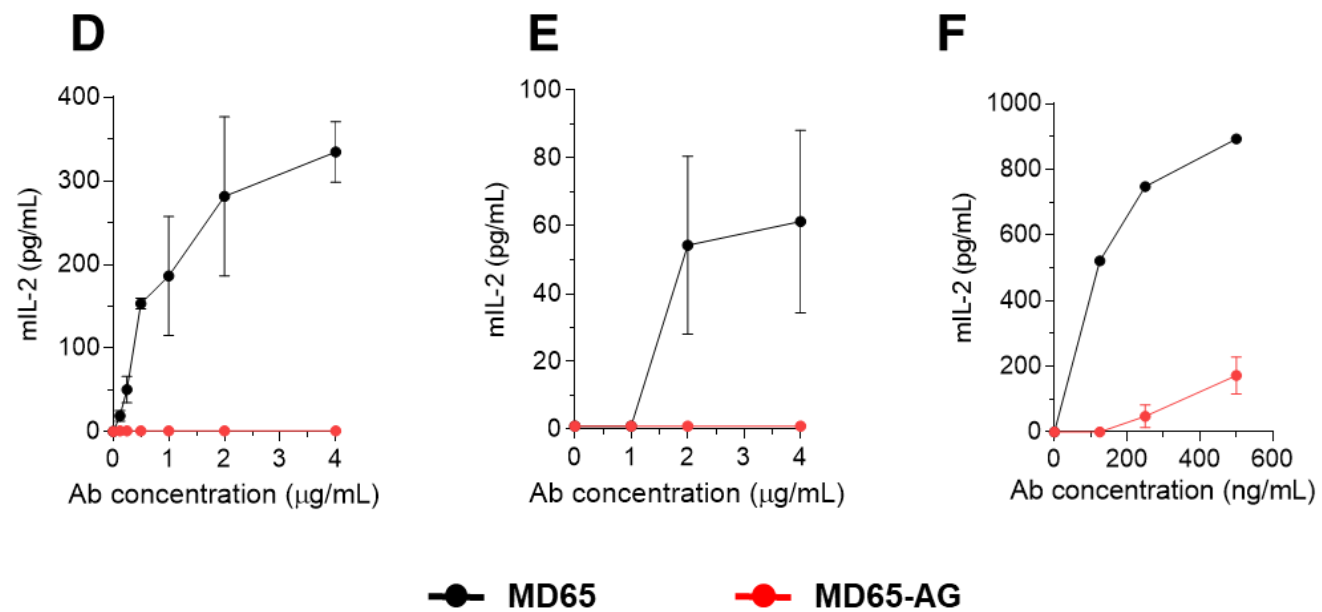

- MD65-AG

Figure 2. Fc $\gamma$ R-mediated activation of cultured cells by the engineered versions of the MD65 mAb. (A) Primary NK cells were incubated for $4.5 \mathrm{~h}$ with increasing concentrations of SARS-CoV-2 spike mixed with non-specific protein (NSP) that were complexed with either MD65 or MD65-AG. Cell-surface expressed CD107a was evaluated by FACS. (B) TNF $\alpha$ or (C) IFN $\gamma$ were measured in the supernatant of the cells that were incubated with spike complexed with the indicated antibody. BW5147 thymoma cells expressing human Fc $\gamma$ receptors (D) CD16, (E) CD32, or (F) CD64 were incubated with spike complexed with antibodies for $16 \mathrm{~h}$. Secreted mIL-2 l-evels were measured by ELISA. Values are averages \pm SEM of duplicates.

\subsection{Prophylactic Activity of MD65-AG In-Vivo}

After it was established that the AG version of the MD65 antibody does not interact and activate the immune system via the Fc-dependent mechanisms, we sought to test its in-vivo activity. The K18-hACE2 transgenic mice model was shown to faithfully recapitulate SARS-CoV-2 infections and serve as a reliable model to evaluate the efficacy of therapeutic strategies [48-51]. The strong K18 promoter confers efficient transgene expression in airway epithelial cells, as well as in other internal organs, including the lungs, heart, brain and spleen. A high number of hACE2 transgene insertions were reported for these mice, resulting in severe illness following SARS-CoV-2 infection, and a high mortality rate [50,52]. We have recently applied this animal model and demonstrated that infection with a dose as low as 300 pfu of SARS-CoV-2 BavPat1/2020 strain, results in significant weight loss from day five after infection and death of $80 \%$ of the animals by day nine post-infection $[4,33]$. It was also shown that treatment of SARS-CoV-2 infected mice with MD65 provided complete protection [4]. Based on our previous experience, the bioavailability of MD65 following IP administration is high, reaching plasma concentration peaks within $180 \mathrm{~min}$ and clearing with a half-life of about 4 days [4]. It was thus important to assess whether the triple mutation incorporated into the Fc region of MD65-AG affects its pharmacokinetics parameters. As the clearance behavior of an antibody is a function of its affinity toward $\mathrm{FcRn}$ at low $\mathrm{pH}$, we measured these parameters using BLI. Indeed, it was found that MD65-AG has retained the binding characteristics to FcRn (steady-state KD of 53 nM; Figure S1).

Next, mice were intranasally (IN) infected with SARS-CoV-2 and concomitantly administered with $1 \mathrm{mg}$ of either MD65 or MD65-AG, intraperitoneally (IP). The clinical effect of the treatment of the two MD65 versions was then evaluated by measuring lung SARS-CoV-2 viral loads in infected mice six days post-infection (the latest time point before mortality onset [4]). We employed qRT-PCR for the quantification of viral burden. In the control non-treated group, as expected, the virus propagated and reached very high concentrations (Figure 3A). In contrast, treatment with either MD65 or AG resulted in significantly lower pulmonary viral loads by more than an order of magnitude compared to the untreated group (Figure 3A). Further evaluation of the infectivity of the virus in these samples (by measuring its ability to infect VERO E6 cells), confirmed the qRT-PCR results and showed that treatment of infected mice with MD65 (either version) significantly inhib- 
ited ( 100-fold decrease) the ability of the virus to propagate with no apparent difference in effect between the antibody version used (Figure 3B).

A

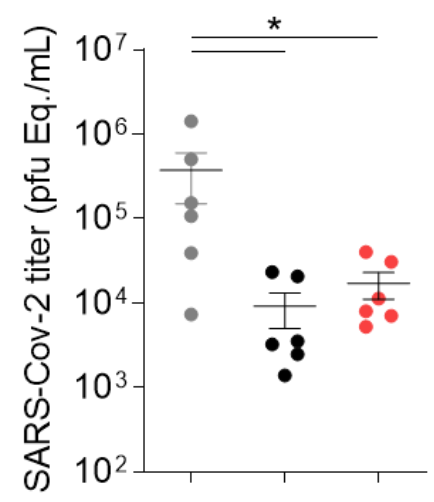

C

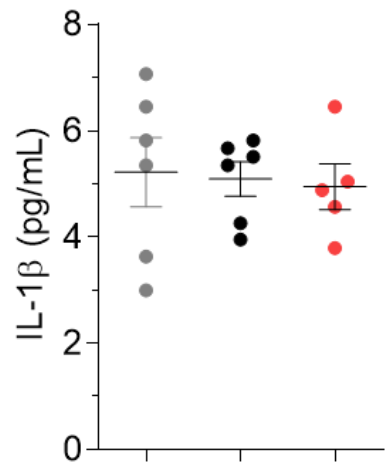

$\mathbf{E}$

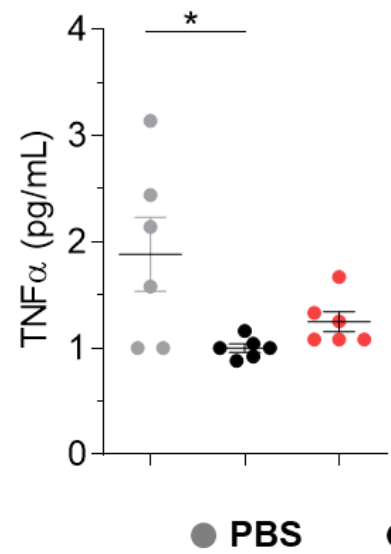

B

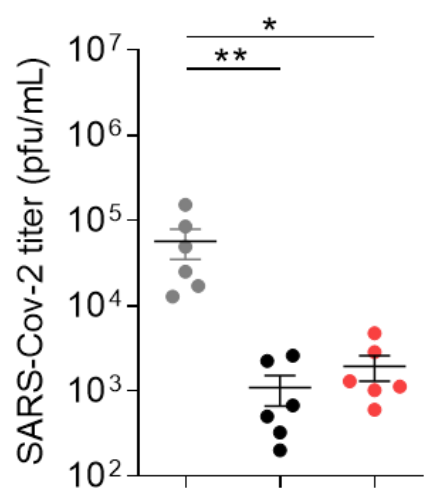

D

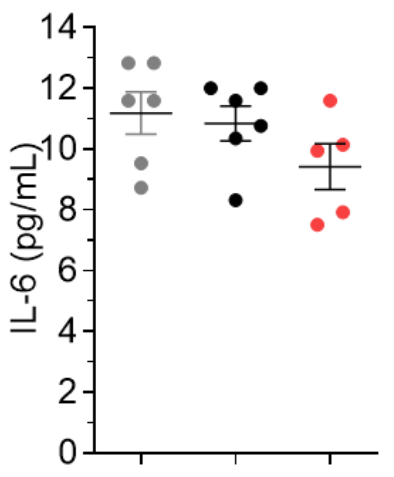

$\mathbf{F}$

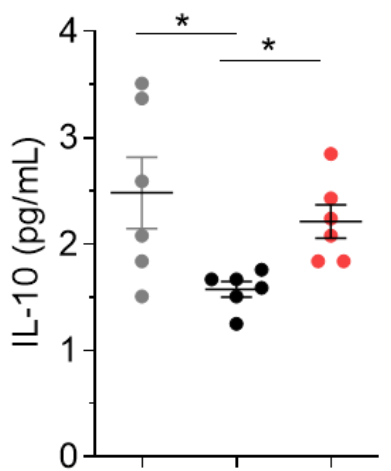

Figure 3. Viral load and cytokine levels following prophylactic administration of MD65 mAb versions. Lung and sera samples were collected six dpi from infected mice treated with the indicated MD65 versions or with PBS as control ( $n=6$ for each group). (A) Viral load was quantified by qRT-PCR and expressed as equivalents of PFU/mL. (B) Infectious viral load determined by plaque assay. Cytokines levels in the sera were measured by multiplex kit (C) IL-1 $\beta$, (D) IL-6, (E) TNF $\alpha$ and (F) IL-10. Data represent individual values and mean \pm SEM. Horizontal bars indicate statistical significance between paired groups as determined by Kruskal-Wallis test $\left({ }^{*} p<0.05,{ }^{* *} p<0.01\right)$. 
The severity of disease in the K18-hACE2 model is also evident as overexpression of pro-inflammatory cytokines [53]. Based on the above results, it was speculated that the treatment will also reduce the serum levels of the pro-inflammatory cytokines. Thus, cytokines levels were measured in sera of mice infected with SARS-CoV-2 and either treated with MD65 or MD65-AG and compared to non-treated animals. The levels of the pro-inflammatory cytokines IL-1b and IL-6 were not affected by either antibody treatment (Figure 3C,D). In contrast, mice that were treated with MD65 exhibited significantly reduced levels of TNF $\alpha$ and IL-10, compared to untreated mice (Figure 3E,F). Interestingly, while MD65-AG treated mice also displayed reduced levels of these two cytokines, this reduction was lesser than that observed for MD65-treated mice (Figure 3E,F). One of the major roles of Fc $\gamma \mathrm{R}$ mediated activation of the immune system is to modify the expression of cytokines in response to infection [7]. Accordingly, it is logical to assume that the incapability of MD65-AG to interact with Fc $\gamma \mathrm{R}$ is affecting the cytokine profile response. Although a more detailed study is needed in order to assess the actual effect of the a-glycosylated antibody on cytokine profile, these changes apparently are not essential for the antibody's ability to induce efficient virus clearance.

\subsection{Fc-Independent Post-Exposure Protection of SARS-CoV-2 Infected Mice}

The observation that when given as prophylaxis, MD65 activity is Fc-independent might reflect direct interactions with the virus, inhibiting its ability to propagate and disseminate. While similar results were shown for several anti-SARS-CoV-2 antibodies, they all failed to confer protection when given post-infection, enforcing the notion that they mainly play a role in neutralizing the first steps of infection, before virus proliferation and spread $[26,27,54]$. Therefore, it was of high importance to evaluate the relevance of Fc-mediated activation in MD65-based therapy in post-exposure treatment of SARSCoV-2 infected K18-hACE2. To this end, mice were infected with 300 pfu of the SARSCoV-2 BavPat1/2020 strain, treated two days post-infection (dpi) with $1 \mathrm{mg}$ of either MD65, MD65-AG or vehicle only (PBS) and further monitored up to $21 \mathrm{dpi}$. As expected, $80 \%$ of the infected animals of the vehicle-treated group have succumbed within 7 to 11 dpi (Figure 4A), with a mean time to death of 8.5 days. In contrast, treatment with either version of the MD65 antibodies was highly efficient in blocking disease progression, completely preventing weight loss and most notably, fully protecting infected mice from death (Figure 4A,B).

It was previously shown that SARS-CoV-2 infection of K18-hACE2 mice manifests as progressive and widespread viral pneumonia with perivascular and pan-alveolar inflammation, immune cell infiltration, edema, lung consolidation and distinctive vascular system injury that were apparent even three weeks after infection (in surviving animals) [50,53,55]. We have previously demonstrated that MD65 based post-exposure treatment of SARSCoV-2 infected K18-hACE2 mice, markedly prevented the formation of these pathological changes [4]. Following the demonstration of the clinical efficacy of MD65 in treating infected mice, it was important to establish the pathological status of their lungs, especially in light of the fact that the activation of the immune system plays a major role in these changes. Accordingly, lung necropsy was performed $21 \mathrm{dpi}$ in mice that were infected and treated as described with either MD65 or MD65-AG. Histological evaluation demonstrated the lack of any major lung pathological changes or inflammation following treatment with either antibody (Figure 4C,D). In accordance with our previous study, the only indication for a previous viral infection was the presence of scarce and well contained lymphoid aggregates, without any major differences between the MD65 and the MD65-AG treated groups. The infiltration and accumulation of B-cells in the lungs of K18-hACE2 mice infected by SARS-CoV-2 were previously documented [53]. The lymphoid aggregates observed in this study most probably contain B-cells that were recruited during the initial accumulation of the virus in the lungs, within the first days after infection. Yet, the antibody treatment has halted the virus' ability to further propagate and thus prevented the progression of inflammation. The observation that both antibody treatments were equally effective, 
further substantiates the conclusion that efficient MD65-based protection of SARS-CoV-2 in-vivo is Fc-independent, even in situations where the virus has already begun propagation and dissemination.

A

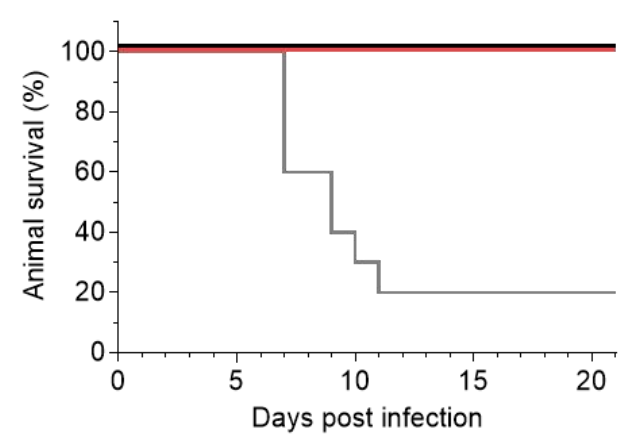

B

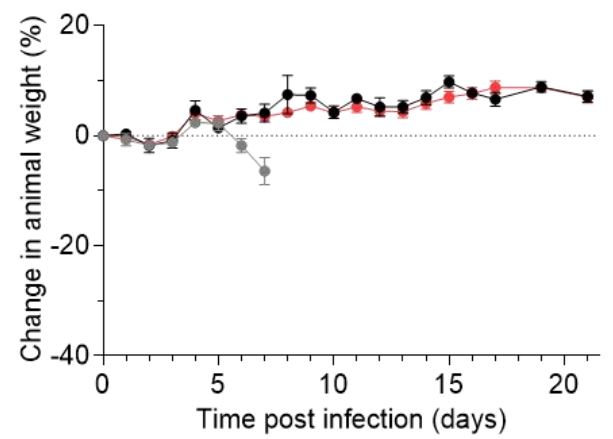

C

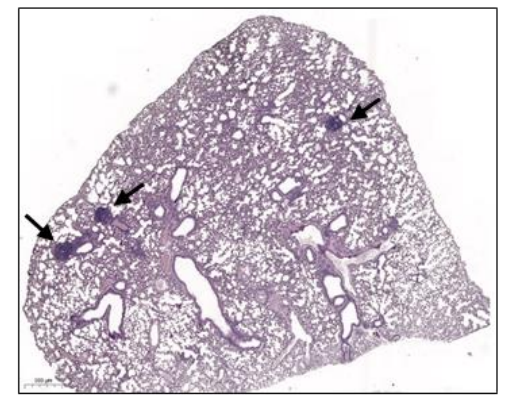

D

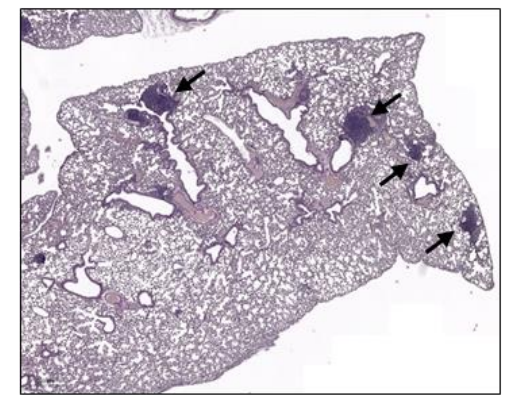

E

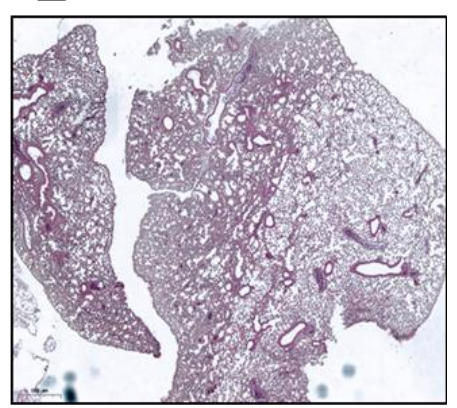

PBS MD65

MD65-AG

Figure 4. MD65 mAb-mediated post-exposure protection against SARS-CoV-2 infection of K18-hACE2 mice. Animals were intranasally infected with SARS-CoV-2 and treated two days later with $1 \mathrm{mg} / \mathrm{mouse}$ of MD65 ( $n=3)$, MD65-AG ( $n=10)$ or with PBS as vehicle-control $(n=10)$. (A) Kaplan-Meyer surviving curves. (B) Bodyweight profiles (data represents mean \pm SEM). (C-E) Representative histological analysis of lung sections collected 21 dpi from MD65-AG (C), MD65 (D) treated mice, or (E) untreated mice (collected $5 \mathrm{dpi}$ ). Black arrows indicate lymphoid aggregates.

\subsection{Dose-Dependent Therapeutic Efficacy of MD65-AG}

While the data so far indicated that efficient post-exposure protection of SARS-CoV-2 infected mice is Fc-independent, we asked whether Fc-immune activation may prove beneficial if treatment is given under sub-optimal conditions. One possible setup for such a challenge is to decrease the antibody:virus ratio, either by treatment at later time points or preferably, by decreasing the initial antibody dosage given at a constant time point. Thus, SARS-CoV-2 infected K18-hACE2 mice were treated two dpi with either $100 \mu \mathrm{g}$ or $10 \mu \mathrm{g}$ doses of antibodies. Treatment with $100 \mu \mathrm{g}$ of MD65 resulted in full protection of all treated mice, with no apparent signs of morbidity (Figure 5A,B). In the parallel group, treated with MD65 AG, 83\% of the animals survived (Figure 5A), with only one animal succumbing to infection. By monitoring animal weight as a surrogate marker for their overall clinical status, a short and transient decrease was observed around day eight in the MD65 -AG group (Figure 5B). Yet, the treated animals quickly recovered and returned to their initial weight. These results fit well with the pharmacokinetics parameters of MD65 [4], where at day eight its concentration in the blood is reduced by more than $70 \%$. At this time point, the low dose together with antibody clearance and the inability to activate the immune system might combine to reduce treatment efficacy. Nevertheless, it had no significant effect on the treatment outcome, as the animals recovered and survived. 


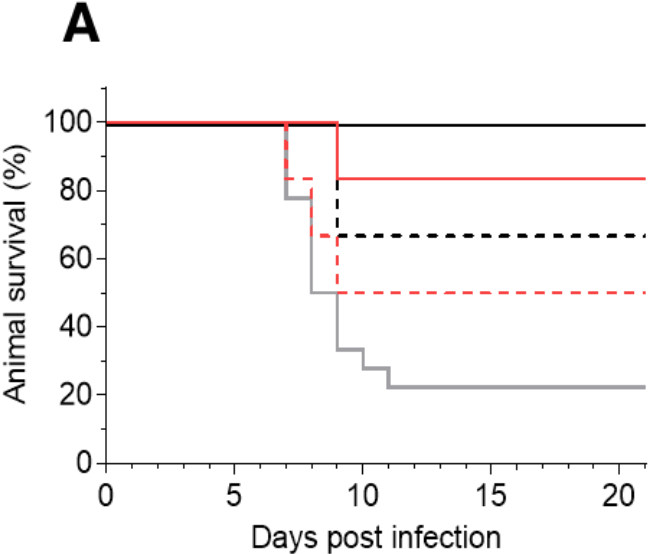

B

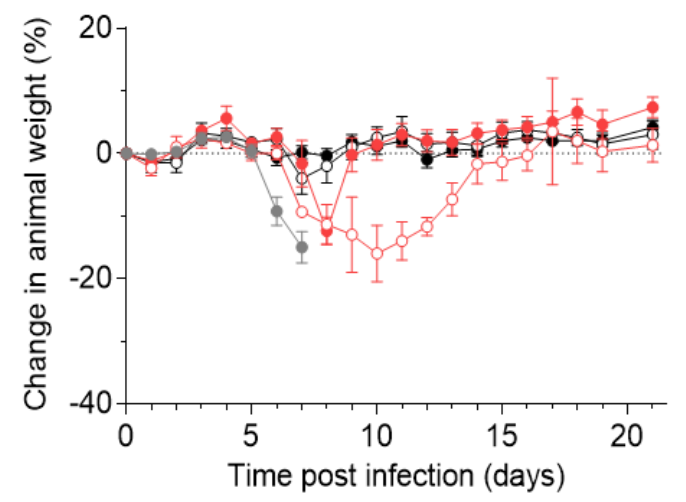

MD65 MD65-AG

Figure 5. Dose-dependent post-exposure protection against SARS-CoV-2 infection of K18-hACE2 mice. Animals were intranasally infected with SARS-CoV-2 and treated two days later with either $100 \mu \mathrm{g} / \mathrm{mouse}$ (full lines) or $10 \mu \mathrm{g} / \mathrm{mouse}$ (dashed lines) of MD65 ( $n=6$ for each group), MD65-AG ( $n=6$ for each group) or with PBS as control ( $n=8)$. (A) KaplanMeyer surviving curves. (B) Bodyweight profiles (empty and filled circles indicate treatment with $10 \mathrm{or} 100 \mu \mathrm{g} / \mathrm{mouse}$, respectively; data represents mean \pm SEM).

Further reducing the antibody dose to $10 \mu \mathrm{g}$ (100 times lower than the original dose) presented a similar trend. Treatment with either MD65 or MD65-AG resulted in the survival of $67 \%$ and $50 \%$ of the animals, respectively (Figure 5A). In the MD65-AG treated group, a marked reduction in the averaged animal's weight was observed between days 7-14, at which time the surviving animals have fully recovered and returned to their initial weight (Figure 5B). Accordingly, it may be concluded that even at sub-optimal treatment conditions, SARS-CoV-2 neutralization and protection is mostly Fc-independent. Yet, in the stage where antibody levels in the circulation are significantly low and the virus was not fully cleared, the recruitment of the immune system via Fc-activation will shorten the duration of the disease.

\subsection{Fc-Independent Post-Exposure Protection by Anti-NTD Antibody}

In order to demonstrate that the potent Fc-independent protection against SARS-CoV-2 is not restricted to one selected antibody, we have chosen an additional anti-SARS-CoV-2 antibody, exhibiting a different neutralization mechanism. We and others have recently demonstrated that efficient neutralization of SARS-CoV-2 can be obtained by targeting the $\mathrm{N}$-terminal domain (NTD), which does not directly interact with the host cell receptor $[23,33]$. The human-derived anti-NTD antibody BLN1 [33] was expressed in the two formats using the same constant regions as those used for the MD65 antibodies. The binding of the two antibody versions was evaluated using ELISA against the spike protein, yielding a similar pattern with an apparent KD of $1.3 \mathrm{nM}$ versus $0.7 \mathrm{nM}$, for BLN1 and the BLN1AG, respectively (Figure 6A). Accordingly, the two BLN1 formats exhibited comparable SARS-CoV-2 neutralization potency in-vitro, with IC50 values of $20-40 \mathrm{ng} / \mathrm{mL}$ (Figure 6B).

The neutralization efficacy of this antibody was further evaluated in the K18-hACE2 mice model. So far, the binding and the in-vitro parameters of antibody BLN1 were highly similar to those determined for MD65. Thus, we decided to perform the in-vivo experiment in the stringent format, initiating treatment two days post-infection, and using the lower dose of $100 \mu \mathrm{g}$ of either version of BLN1. Indeed, in this setting, treatment of the infected group with BLN1 resulted in the protection of $83 \%$ of the animals (Figure $6 \mathrm{C}$ ) with one death on day nine. The surviving animals showed no sign of illness or morbidity, as evident by weight monitoring (Figure 6D). Similar results were obtained in the experimental group that was treated with BLN1-AG, where one animal succumbed on day 13, also resulting in $83 \%$ survival (Figure 6C). It is also interesting to note that, unlike the MD65-AG group, 
no weight loss (or any other clinical signs) was observed in the group that was treated with BLN1 AG (Figure 6D). Taken together, these results suggest that efficient in-vivo antibody-based neutralization of SARS-CoV-2 is Fc-independent, regardless of the specific molecular neutralization mechanisms.
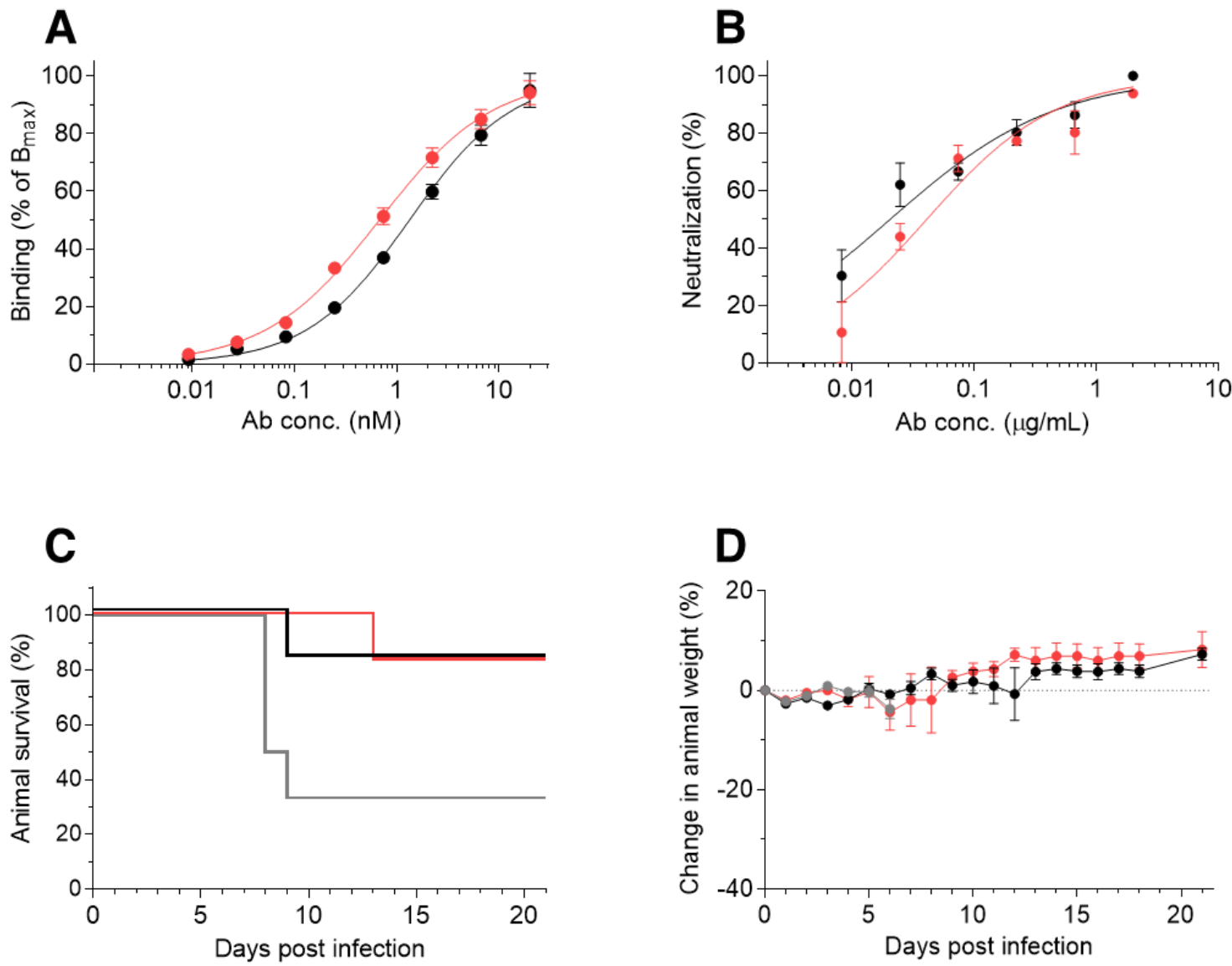

PBS

- BLN1

BLN1-AG

Figure 6. BLN1 mAb-mediated post-exposure protection against SARS-CoV-2 infection of K18-hACE2 mice. (A) Antibodies binding to immobilized SARS-CoV-2 spike protein. (B) in-vitro neutralization of SARS-CoV-2, by PRNT. (C,D) Animals were intranasally infected with SARS-CoV-2 and two days later treated with $100 \mu \mathrm{g} /$ mouse of BLN1 $(n=6)$, BLN1-AG $(n=6)$ or with PBS as control $(n=6)$. (C) Kaplan-Meyer surviving curves. (D) Bodyweight profiles (data represents mean \pm SEM).

\section{Discussion}

Delineation of the role and impact of Fc-mediated activity in antibody-based passive protection against SARS-CoV-2 infection is of high interest and would assist in the design of such therapeutics. In this study, we have shown that two highly potent SARS-CoV-2 neutralizing antibodies do not rely on Fc-mediated immune activation to properly protect infected K18-hACE2 mice against lethal challenges.

With the aim of interfering with Fc-mediated effector functions, numerous mutations were examined, targeting amino acid positions that were found to interact with Fc $\gamma \mathrm{R}$ and the complement cascade [45,56-61]. However, since each of the proteins, involved in effector functions, interacts with the antibody's Fc at slightly different positions, different sets of point mutations can either eliminate binding to a specific receptor or partially reduce binding to all receptors. One commonly used set of mutations creating an Fc-null antibody is L234A/L235A (LALA mutations) [62]. These mutations are directed at two points involved in the interaction between $\mathrm{Fc}_{\mathrm{c}}$ and $\mathrm{Fc} \gamma \mathrm{R}$. The LALA mutations were shown to reduce ADCC activity [63] and dramatically reduce binding to Fc $\gamma$ RI, IIa and IIIa [62]. 
Nevertheless, the introduction of the LALA mutations was demonstrated to allow minimal, but detectable, activity [29]. Indeed, the addition of a third mutation, P329G (LALA-PG), was needed to completely abrogate the binding of antibodies to the Fc $\gamma \mathrm{R}$ [64]. Here, we took an alternative approach to eliminate the activation of Fc-mediated functions, by inserting a triple mutation that eliminates Fc-glycosylation. The N-linked glycosylation of the Fc was shown to be involved in all types of effector functions, including antibodydependent cellular cytotoxicity (ADCC), antibody-dependent cellular phagocytosis (ADCP) and cell-dependent cytotoxicity (CDC). It was therefore, expected that the elimination of glycosylation will abolish all such functions [37]. In addition to type I Fc $\gamma$ R, the Fc domain also interacts with type II FcR's, which are C-type lectin receptors, CD209 (DC-SIGN) and CD23 [65]. These receptors mainly bind sialylated-Fc domains of IgG antibodies and are involved in the regulation of inflammation and B-cell selection [66]. Although not tested in the current study, it can be assumed that the absence of glycosylation also eliminates the binding of the Fc domain by these receptors.

Despite the interest in understanding the role of Fc in the in-vivo neutralization of SARS-CoV-2, only limited studies have addressed this point so far. Two studies have performed a side-by-side comparison of the in-vivo activity of a mutated Fc (LALA or LALA-PG) versus a fully active antibody $[27,28]$. Both studies have found that treatment outcome, when given post-exposure (2-24 h post-infection), was markedly affected if Fc-mediated activity was abrogated. Two other studies have also evaluated the activity of similarly mutated Fc and found that if given post-exposure, their ability to protect animals from SARS CoV-2 infection, was inferior to prophylactic treatment [26,54]. Yet, these studies did not include a comparison with non-mutated antibodies, and thus the results could not be unequivocally attributed to the lack of Fc-activation. Based on their results in the K18-hACE2 model, Winkler et al. [27] suggested that once the virus has already begun to propagate and disseminate, effective protection requires Fc-mediated effector activity of the immune system. In contrast to the above-mentioned works, we have demonstrated that effective antibody-based therapy of SARS-CoV-2 infection in the stringent K18-hACE2 mice model can be achieved without the activation of the Fc-dependent effector functions. Moreover, this observation was confirmed by using two antibodies, each targeting and neutralizing SARS-CoV-2 by totally distinct mechanisms. One possible explanation for this apparent discrepancy is that antibodies that possess high neutralization activity, may be able to exert their direct activity even at delayed time points post-infection, thus making Fcdependent functions redundant. Both MD65 and BLN1 belong to a potent set of antibodies that were shown to protect SARS-CoV-2 infected mice even when treatment was initiated 2-3 days post-exposure [4,33]. Although a higher number of potent antibodies should be tested in order to make a broader and general conclusion, it is suggested that the antibodies presented here can be regarded as a unique set of neutralizing antibodies, for whom favorable clinical outcome does not necessitate the activation of Fc-mediated functions.

It was previously shown that treatment of SARS CoV-2 infected K18-hACE mice, by administration of $1 \mathrm{mg}$ MD65 antibody, was highly effective when given up to 3 days post-infection [4] In the current study, MD65-AG was tested using this therapeutic dose only when given 2 days post-infection, resulting in full protection as the glycosylated antibody. It is, therefore, logical to assume that treatment using MD65-AG at the same dose ( $1 \mathrm{mg}$ ) will be as effective, even if given at later time points, similar to the results obtained using MD65. Only following treatment with very low antibody dosage, a slight beneficial effect of Fc-activation was observed, with mice treated with MD65 not showing signs of illness while those treated with MD65-AG exhibited a transient reduction in body weight from day 7-14. While the YTE mutations increased antibody affinity towards the human FcRn at acidic $\mathrm{pH}$ and prolonged its serum half-life in humans up to several months, it did not affect the pharmacokinetics in mouse sera. In fact, we have found that MD65, harboring the YTE mutations, has a serum half-life of about 3.5 days [4] in C57BL/6 mice (which share the same genetic background as K18-hACE2). Thus, the clinical signs observed here from day seven, correlate with a significant drop in antibody levels to about $20 \%$ of the 
initial values. Although not examined here, it can be speculated that if MD65-AG levels were kept constant for several days, then mice would not exhibit any signs of disease even if treated with such low and suboptimal doses.

While in this study we have employed a mouse model to study the role of Fc in the treatment of COVID-19, the loss-of-function triple mutations (AG) that were inserted were aimed at abrogating the activation of the human Fc-mediated effector functions. Nevertheless, it was previously shown that various human IgG isotypes activate murine effector cells and that the human IgG1 is the most potent activator of ADCC and antibodydependent cellular phagocytosis in the mouse [67]. Thus, we believe that based on the clear overlap in the human IgG1 ability to activate murine Fc-effector functions, the K18-hACE2 infection model would reliably predict the behavior of Fc-engineered antibodies in humans.

To summarize, this study demonstrated that antibodies MD65 and BLN1 do not necessarily require the modulation of the immune system and that their therapeutic efficacy may be a result of very efficient inhibition of viral dissemination in the body. Moreover, these results provide important insights regarding the contribution of Fc-effector functions in antibody-mediated protection, which should aid in the future design of effective antibody-based therapies.

Supplementary Materials: The following are available online at https:/ /www.mdpi.com/article/10 .3390/antib10040045/s1, Figure S1: Binding of MD65-AG to hFcRn.

Author Contributions: Conceptualization, T.N.-P., A.E., H.M., A.P., R.R. and O.M.; methodology and investigation, T.N.-P., A.E., R.A., E.M., D.G., M.A., Y.E., A.B.-D., Y.L., E.E., O.R., A.Z. and S.L.; writing-review and editing, T.N.-P., S.Y., H.M., A.P., R.R. and O.M.; supervision, A.P., R.R. and O.M. All authors have read and agreed to the published version of the manuscript.

Funding: Part of this study was funded by the Israel Science Foundation grant: 2484/19 (A.P.)

Institutional Review Board Statement: Animal studies were conducted according to the guidelines and regulations outlined in the U.S. Department of Agriculture (USDA) Animal Welfare Act and the conditions specified in the Guide for Care and Use of Laboratory Animals (National Institute of Health, 2011) and approved by IIBR ethical committee on animal experiments (protocol number M-51-20 approved on August 2020).

Data Availability Statement: No new data were created or analyzed in this study.

Acknowledgments: We wish to express our gratitude to our colleagues Adva Mechaly, Tomer Israely, Sharon Melamed, Hagit Achdout, Yfat Yahalom-Ronen, Hadas Tamir, Emanuelle Mamroud, Shay Weiss, Itai Glinert, Theodor Chitlaru, Moshe Manzur, Yaron Vagima, Liat Bar-On, Noa MadarBalakirski, Amir Rosner, Hila Gutman and Shmuel C. Shapira for fruitful discussions and support.

Conflicts of Interest: Patent application for the described antibodies was filed by the Israel Institute for Biological Research. O.M. is an Editorial Board Member of Antibodies. None of the authors declared any additional competing interests.

\section{References}

1. Chen, Z.; Bao, L.; Chen, C.; Zou, T.; Xue, Y.; Li, F.; Lv, Q.; Gu, S.; Gao, X.; Cui, S.; et al. Human Neutralizing Monoclonal Antibody Inhibition of Middle East Respiratory Syndrome Coronavirus Replication in the Common Marmoset. J. Infect. Dis. 2017, 215, 1807-1815. [CrossRef]

2. Corti, D.; Zhao, J.; Pedotti, M.; Simonelli, L.; Agnihothram, S.; Fett, C.; Fernandez-Rodriguez, B.; Foglierini, M.; Agatic, G.; Vanzetta, F.; et al. Prophylactic and postexposure efficacy of a potent human monoclonal antibody against MERS coronavirus. Proc. Natl. Acad. Sci. USA 2015, 112, 10473-10478. [CrossRef]

3. Rockx, B.; Corti, D.; Donaldson, E.; Sheahan, T.; Stadler, K.; Lanzavecchia, A.; Baric, R. Structural basis for potent cross-neutralizing human monoclonal antibody protection against lethal human and zoonotic severe acute respiratory syndrome coronavirus challenge. J. Virol. 2008, 82, 3220-3235. [CrossRef] [PubMed]

4. Rosenfeld, R.; Noy-Porat, T.; Mechaly, A.; Makdasi, E.; Levy, Y.; Alcalay, R.; Falach, R.; Aftalion, M.; Epstein, E.; Gur, D.; et al. Post-exposure protection of SARS-CoV-2 lethal infected K18-hACE2 transgenic mice by neutralizing human monoclonal antibody. Nat. Commun. 2021, 12, 944. [CrossRef] 
5. Scheid, J.F.; Mouquet, H.; Feldhahn, N.; Seaman, M.S.; Velinzon, K.; Pietzsch, J.; Ott, R.G.; Anthony, R.M.; Zebroski, H.; Hurley, A.; et al. Broad diversity of neutralizing antibodies isolated from memory B cells in HIV-infected individuals. Nature 2009, 458, 636-640. [CrossRef] [PubMed]

6. Zhu, Z.; Chakraborti, S.; He, Y.; Roberts, A.; Sheahan, T.; Xiao, X.; Hensley, L.E.; Prabakaran, P.; Rockx, B.; Sidorov, I.A.; et al. Potent cross-reactive neutralization of SARS coronavirus isolates by human monoclonal antibodies. Proc. Natl. Acad. Sci. USA 2007, 104, 12123-12128. [CrossRef]

7. Lu, L.L.; Suscovich, T.J.; Fortune, S.M.; Alter, G. Beyond binding: Antibody effector functions in infectious diseases. Nat. Rev. Immunol. 2018, 18, 46-61. [CrossRef]

8. Chan, K.R.; Ong, E.Z.; Mok, D.Z.; Ooi, E.E. Fc receptors and their influence on efficacy of therapeutic antibodies for treatment of viral diseases. Expert. Rev. Anti. Infect. Ther. 2015, 13, 1351-1360. [CrossRef] [PubMed]

9. Hajishengallis, G.; Reis, E.S.; Mastellos, D.C.; Ricklin, D.; Lambris, J.D. Novel mechanisms and functions of complement. Nat. Immunol. 2017, 18, 1288-1298. [CrossRef]

10. Junker, F.; Gordon, J.; Qureshi, O. Fc Gamma Receptors and Their Role in Antigen Uptake, Presentation, and T Cell Activation. Front. Immunol. 2020, 11, 1393. [CrossRef]

11. DiLillo, D.J.; Palese, P.; Wilson, P.C.; Ravetch, J.V. Broadly neutralizing anti-influenza antibodies require Fc receptor engagement for in vivo protection. J. Clin. Investig. 2016, 126, 605-610. [CrossRef]

12. Earnest, J.T.; Holmes, A.C.; Basore, K.; Mack, M.; Fremont, D.H.; Diamond, M.S. The mechanistic basis of protection by non-neutralizing anti-alphavirus antibodies. Cell Rep. 2021, 35, 108962. [CrossRef]

13. Gunn, B.M.; Yu, W.; Karim, M.M.; Brannan, J.M.; Herbert, A.S.; Wec, A.Z.; Halfmann, P.J.; Fusco, M.L.; Schendel, S.L.; Gangavarapu, K.; et al. A Role for Fc Function in Therapeutic Monoclonal Antibody-Mediated Protection against Ebola Virus. Cell Host Microbe 2018, 24, 221-233.e5. [CrossRef]

14. Liu, Y.; Tan, H.X.; Koutsakos, M.; Jegaskanda, S.; Esterbauer, R.; Tilmanis, D.; Aban, M.; Kedzierska, K.; Hurt, A.C.; Kent, S.J.; et al. Cross-lineage protection by human antibodies binding the influenza B hemagglutinin. Nat. Commun. 2019, 10, 324. [CrossRef]

15. Parsons, M.S.; Lee, W.S.; Kristensen, A.B.; Amarasena, T.; Khoury, G.; Wheatley, A.K.; Reynaldi, A.; Wines, B.D.; Hogarth, M.; Davenport, M.P.; et al. Fc-dependent functions are redundant to efficacy of anti-HIV antibody PGT121 in macaques. J. Clin. Investig. 2019, 129, 182-191. [CrossRef]

16. Baum, A.; Fulton, B.O.; Wloga, E.; Copin, R.; Pascal, K.E.; Russo, V.; Giordano, S.; Lanza, K.; Negron, N.; Ni, M.; et al. Antibody cocktail to SARS-CoV-2 spike protein prevents rapid mutational escape seen with individual antibodies. Science 2020, 369, 1014-1018. [CrossRef] [PubMed]

17. Weinreich, D.M.; Sivapalasingam, S.; Norton, T.; Ali, S.; Gao, H.; Bhore, R.; Musser, B.J.; Soo, Y.; Rofail, D.; Im, J.; et al. REGN-COV2, a Neutralizing Antibody Cocktail, in Outpatients with Covid-19. N. Engl. J. Med. 2021, 384, 238-251. [CrossRef] [PubMed]

18. Brouwer, P.J.M.; Caniels, T.G.; van der Straten, K.; Snitselaar, J.L.; Aldon, Y.; Bangaru, S.; Torres, J.L.; Okba, N.M.A.; Claireaux, M.; Kerster, G.; et al. Potent neutralizing antibodies from COVID-19 patients define multiple targets of vulnerability. Science 2020, 369, 643-650. [CrossRef] [PubMed]

19. Cao, Y.; Su, B.; Guo, X.; Sun, W.; Deng, Y.; Bao, L.; Zhu, Q.; Zhang, X.; Zheng, Y.; Geng, C.; et al. Potent Neutralizing Antibodies against SARS-CoV-2 Identified by High-Throughput Single-Cell Sequencing of Convalescent Patients' B Cells. Cell 2020, 182, 73-84.e16. [CrossRef]

20. Ju, B.; Zhang, Q.; Ge, J.; Wang, R.; Sun, J.; Ge, X.; Yu, J.; Shan, S.; Zhou, B.; Song, S.; et al. Human neutralizing antibodies elicited by SARS-CoV-2 infection. Nature 2020, 584, 115-119. [CrossRef]

21. Liu, L.; Wang, P.; Nair, M.S.; Yu, J.; Rapp, M.; Wang, Q.; Luo, Y.; Chan, J.F.; Sahi, V.; Figueroa, A.; et al. Potent neutralizing antibodies against multiple epitopes on SARS-CoV-2 spike. Nature 2020, 584, 450-456. [CrossRef]

22. Noy-Porat, T.; Makdasi, E.; Alcalay, R.; Mechaly, A.; Levy, Y.; Bercovich-Kinori, A.; Zauberman, A.; Tamir, H.; Yahalom-Ronen, Y.; Israeli, M.; et al. A panel of human neutralizing mAbs targeting SARS-CoV-2 spike at multiple epitopes. Nat. Commun. 2020, 11, 4303. [CrossRef]

23. Suryadevara, N.; Shrihari, S.; Gilchuk, P.; VanBlargan, L.A.; Binshtein, E.; Zost, S.J.; Nargi, R.S.; Sutton, R.E.; Winkler, E.S.; Chen, E.C.; et al. Neutralizing and protective human monoclonal antibodies recognizing the N-terminal domain of the SARS-CoV-2 spike protein. Cell 2021, 184, 2316-2331.e15. [CrossRef] [PubMed]

24. Atyeo, C.; Slein, M.D.; Fischinger, S.; Burke, J.; Schäfer, A.; Leist, S.R.; Kuzmina, N.A.; Mire, C.; Honko, A.; Johnson, R.; et al. Dissecting strategies to tune the therapeutic potential of SARS-CoV-2-specific monoclonal antibody CR3022. JCI Insight 2021, 6, e143129. [CrossRef] [PubMed]

25. Schafer, A.; Muecksch, F.; Lorenzi, J.C.C.; Leist, S.R.; Cipolla, M.; Bournazos, S.; Schmidt, F.; Maison, R.M.; Gazumyan, A.; Martinez, D.R.; et al. Antibody potency, effector function, and combinations in protection and therapy for SARS-CoV-2 infection in vivo. J. Exp. Med. 2021, 218, e20201993. [CrossRef]

26. Shi, R.; Shan, C.; Duan, X.; Chen, Z.; Liu, P.; Song, J.; Song, T.; Bi, X.; Han, C.; Wu, L.; et al. A human neutralizing antibody targets the receptor-binding site of SARS-CoV-2. Nature 2020, 584, 120-124. [CrossRef] [PubMed]

27. Winkler, E.S.; Gilchuk, P.; Yu, J.; Bailey, A.L.; Chen, R.E.; Chong, Z.; Zost, S.J.; Jang, H.; Huang, Y.; Allen, J.D.; et al. Human neutralizing antibodies against SARS-CoV-2 require intact Fc effector functions for optimal therapeutic protection. Cell 2021, 184, 1804-1820.e1816. [CrossRef] 
28. Chan, C.E.Z.; Seah, S.G.K.; Chye, H.; Massey, S.; Torres, M.; Lim, A.P.C.; Wong, S.K.K.; Neo, J.J.Y.; Wong, P.S.; Lim, J.H.; et al. The Fc-mediated effector functions of a potent SARS-CoV-2 neutralizing antibody, SC31, isolated from an early convalescent COVID-19 patient, are essential for the optimal therapeutic efficacy of the antibody. PLoS ONE 2021, 16, e0253487. [CrossRef]

29. Eroshenko, N.; Gill, T.; Keaveney, M.K.; Church, G.M.; Trevejo, J.M.; Rajaniemi, H. Implications of antibody-dependent enhancement of infection for SARS-CoV-2 countermeasures. Nat. Biotechnol. 2020, 38, 789-791. [CrossRef]

30. Makdasi, E.; Levy, Y.; Alcalay, R.; Noy-Porat, T.; Zahavy, E.; Mechaly, A.; Epstein, E.; Peretz, E.; Cohen, H.; Bar-On, L.; et al. Neutralizing Monoclonal Anti-SARS-CoV-2 Antibodies Isolated from Immunized Rabbits Define Novel Vulnerable Spike-Protein Epitope. Viruses 2021, 13, 566. [CrossRef]

31. Noy-Porat, T.; Alcalay, R.; Mechaly, A.; Peretz, E.; Makdasi, E.; Rosenfeld, R.; Mazor, O. Characterization of antibody-antigen interactions using biolayer interferometry. STAR Protoc. 2021, 2, 100836. [CrossRef] [PubMed]

32. Gaudinski, M.R.; Coates, E.E.; Houser, K.V.; Chen, G.L.; Yamshchikov, G.; Saunders, J.G.; Holman, L.A.; Gordon, I.; Plummer, S.; Hendel, C.S.; et al. Safety and pharmacokinetics of the Fc-modified HIV-1 human monoclonal antibody VRC01LS: A Phase 1 open-label clinical trial in healthy adults. PLoS Med. 2018, 15, e1002493. [CrossRef]

33. Noy-Porat, T.; Mechaly, A.; Levy, Y.; Makdasi, E.; Alcalay, R.; Gur, D.; Aftalion, M.; Falach, R.; Leviatan Ben-Arye, S.; Lazar, S.; et al. Therapeutic antibodies, targeting the SARS-CoV-2 spike N-terminal domain, protect lethally infected K18-hACE2 mice. Iscience 2021, 24, 102479. [CrossRef]

34. Finkel, Y.; Mizrahi, O.; Nachshon, A.; Weingarten-Gabbay, S.; Morgenstern, D.; Yahalom-Ronen, Y.; Tamir, H.; Achdout, H.; Stein, D.; Israeli, O.; et al. The coding capacity of SARS-CoV-2. Nature 2021, 589, 125-130. [CrossRef] [PubMed]

35. Jung, S.T.; Kang, T.H.; Kelton, W.; Georgiou, G. Bypassing glycosylation: Engineering aglycosylated full-length IgG antibodies for human therapy. Curr. Opin. Biotechnol. 2011, 22, 858-867. [CrossRef]

36. Quast, I.; Peschke, B.; Lunemann, J.D. Regulation of antibody effector functions through IgG Fc N-glycosylation. Cell Mol. Life Sci. 2017, 74, 837-847. [CrossRef]

37. Tao, M.H.; Morrison, S.L. Studies of aglycosylated chimeric mouse-human IgG. Role of carbohydrate in the structure and effector functions mediated by the human IgG constant region. J. Immunol. 1989, 143, 2595-2601.

38. Wang, X.; Mathieu, M.; Brezski, R.J. IgG Fc engineering to modulate antibody effector functions. Protein Cell 2018, 9, 63-73. [CrossRef] [PubMed]

39. Sazinsky, S.L.; Ott, R.G.; Silver, N.W.; Tidor, B.; Ravetch, J.V.; Wittrup, K.D. Aglycosylated immunoglobulin G1 variants productively engage activating Fc receptors. Proc. Natl. Acad. Sci. USA 2008, 105, 20167-20172. [CrossRef]

40. Falach, R.; Bar-On, L.; Lazar, S.; Kadar, T.; Mazor, O.; Aftalion, M.; Gur, D.; Evgy, Y.; Shifman, O.; Aminov, T.; et al. Mice with induced pulmonary morbidities display severe lung inflammation and mortality following exposure to SARS-CoV-2. JCI Insight 2021, 6, e145916. [CrossRef]

41. Makdasi, E.; Zvi, A.; Alcalay, R.; Noy-Porat, T.; Peretz, E.; Mechaly, A.; Levy, Y.; Epstein, E.; Chitlaru, T.; Tennenhouse, A.; et al. The neutralization potency of anti-SARS-CoV-2 therapeutic human monoclonal antibodies is retained against viral variants. Cell Rep. 2021, 36, 109679. [CrossRef]

42. Oganesyan, V.; Damschroder, M.M.; Cook, K.E.; Li, Q.; Gao, C.; Wu, H.; Dall'Acqua, W.F. Structural insights into neonatal Fc receptor-based recycling mechanism. J. Biol. Chem. 2014, 289, 7812-7824. [CrossRef]

43. Yu, X.Q.; Robbie, G.J.; Wu, Y.; Esser, M.T.; Jensen, K.; Schwartz, H.I.; Bellamy, T.; Hernandez-Illas, M.; Jafri, H.S. Safety, Tolerability, and Pharmacokinetics of MEDI4893, an Investigational, Extended-Half-Life, Anti-Staphylococcus aureus Alpha-Toxin Human Monoclonal Antibody, in Healthy Adults. Antimicrob. Agents Chemother. 2017, 61. [CrossRef]

44. Dall'Acqua, W.F.; Kiener, P.A.; Wu, H. Properties of human IgG1s engineered for enhanced binding to the neonatal Fc receptor. J. Biol. Chem. 2006, 281, 23514-23524. [CrossRef]

45. Saunders, K.O. Conceptual Approaches to Modulating Antibody Effector Functions and Circulation Half-Life. Front. Immunol. 2019, 10, 1296. [CrossRef] [PubMed]

46. Edri, A.; Shemesh, A.; Iraqi, M.; Matalon, O.; Brusilovsky, M.; Hadad, U.; Radinsky, O.; Gershoni-Yahalom, O.; Dye, J.M.; Mandelboim, O.; et al. The Ebola-Glycoprotein Modulates the Function of Natural Killer Cells. Front. Immunol. 2018, 9, 1428. [CrossRef]

47. Radinsky, O.; Edri, A.; Brusilovsky, M.; Fedida-Metula, S.; Sobarzo, A.; Gershoni-Yahalom, O.; Lutwama, J.; Dye, J.; Lobel, L.; Porgador, A. Sudan ebolavirus long recovered survivors produce GP-specific Abs that are of the IgG1 subclass and preferentially bind FcgammaRI. Sci. Rep. 2017, 7, 6054. [CrossRef] [PubMed]

48. Golden, J.W.; Cline, C.R.; Zeng, X.; Garrison, A.R.; Carey, B.D.; Mucker, E.M.; White, L.E.; Shamblin, J.D.; Brocato, R.L.; Liu, J.; et al. Human angiotensin-converting enzyme 2 transgenic mice infected with SARS-CoV-2 develop severe and fatal respiratory disease. JCI Insight 2020, 5, e142032. [CrossRef]

49. Jia, H.; Yue, X.; Lazartigues, E. ACE2 mouse models: A toolbox for cardiovascular and pulmonary research. Nat. Commun. 2020, 11, 5165. [CrossRef] [PubMed]

50. Winkler, E.S.; Bailey, A.L.; Kafai, N.M.; Nair, S.; McCune, B.T.; Yu, J.; Fox, J.M.; Chen, R.E.; Earnest, J.T.; Keeler, S.P.; et al. SARS-CoV-2 infection of human ACE2-transgenic mice causes severe lung inflammation and impaired function. Nat. Immunol. 2020, 21, 1327-1335. [CrossRef] 
51. Zheng, J.; Wong, L.R.; Li, K.; Verma, A.K.; Ortiz, M.E.; Wohlford-Lenane, C.; Leidinger, M.R.; Knudson, C.M.; Meyerholz, D.K.; McCray, P.B., Jr.; et al. COVID-19 treatments and pathogenesis including anosmia in K18-hACE2 mice. Nature 2021, 589, 603-607. [CrossRef] [PubMed]

52. McCray, P.B., Jr.; Pewe, L.; Wohlford-Lenane, C.; Hickey, M.; Manzel, L.; Shi, L.; Netland, J.; Jia, H.P.; Halabi, C.; Sigmund, C.D.; et al. Lethal infection of K18-hACE2 mice infected with severe acute respiratory syndrome coronavirus. J. Virol. 2007, 81, 813-821. [CrossRef]

53. Yinda, C.K.; Port, J.R.; Bushmaker, T.; Offei Owusu, I.; Purushotham, J.N.; Avanzato, V.A.; Fischer, R.J.; Schulz, J.E.; Holbrook, M.G.; Hebner, M.J.; et al. K18-hACE2 mice develop respiratory disease resembling severe COVID-19. PLoS Pathog. 2021, 17, e1009195. [CrossRef]

54. Andreano, E.; Nicastri, E.; Paciello, I.; Pileri, P.; Manganaro, N.; Piccini, G.; Manenti, A.; Pantano, E.; Kabanova, A.; Troisi, M.; et al. Extremely potent human monoclonal antibodies from COVID-19 convalescent patients. Cell 2021, 184, 1821-1835.e16. [CrossRef] [PubMed]

55. Oladunni, F.S.; Park, J.G.; Pino, P.A.; Gonzalez, O.; Akhter, A.; Allué-Guardia, A.; Olmo-Fontánez, A.; Gautam, S.; Garcia-Vilanova, A.; Ye, C.; et al. Lethality of SARS-CoV-2 infection in K18 human angiotensin-converting enzyme 2 transgenic mice. Nat. Commun. 2020, 11, 6122. [CrossRef]

56. Idusogie, E.E.; Wong, P.Y.; Presta, L.G.; Gazzano-Santoro, H.; Totpal, K.; Ultsch, M.; Mulkerrin, M.G. Engineered antibodies with increased activity to recruit complement. J. Immunol. 2001, 166, 2571-2575. [CrossRef]

57. Lund, J.; Winter, G.; Jones, P.T.; Pound, J.D.; Tanaka, T.; Walker, M.R.; Artymiuk, P.J.; Arata, Y.; Burton, D.R.; Jefferis, R.; et al. Human Fc gamma RI and Fc gamma RII interact with distinct but overlapping sites on human IgG. J. Immunol. 1991, 147, 2657-2662.

58. Oganesyan, V.; Damschroder, M.M.; Leach, W.; Wu, H.; Dall'Acqua, W.F. Structural characterization of a mutated, ADCCenhanced human Fc fragment. Mol. Immunol. 2008, 45, 1872-1882. [CrossRef]

59. Sarmay, G.; Lund, J.; Rozsnyay, Z.; Gergely, J.; Jefferis, R. Mapping and comparison of the interaction sites on the Fc region of IgG responsible for triggering antibody dependent cellular cytotoxicity ADCC) through different types of human Fc gamma receptor. Mol. Immunol. 1992, 29, 633-639. [CrossRef]

60. Vafa, O.; Gilliland, G.L.; Brezski, R.J.; Strake, B.; Wilkinson, T.; Lacy, E.R.; Scallon, B.; Teplyakov, A.; Malia, T.J.; Strohl, W.R. An engineered Fc variant of an IgG eliminates all immune effector functions via structural perturbations. Methods 2014, 65, 114-126. [CrossRef] [PubMed]

61. Wessels, U.; Poehler, A.; Moheysen-Zadeh, M.; Zadak, M.; Staack, R.F.; Umana, P.; Heinrich, J.; Stubenrauch, K. Detection of antidrug antibodies against human therapeutic antibodies lacking Fc-effector functions by usage of soluble Fcgamma receptor I. Bioanalysis 2016, 8, 2135-2145. [CrossRef]

62. Xu, D.; Alegre, M.L.; Varga, S.S.; Rothermel, A.L.; Collins, A.M.; Pulito, V.L.; Hanna, L.S.; Dolan, K.P.; Parren, P.W.; Bluestone, J.A.; et al. In vitro characterization of five humanized OKT3 effector function variant antibodies. Cell Immunol. 2000, 200, 16-26. [CrossRef]

63. Hezareh, M.; Hessell, A.J.; Jensen, R.C.; van de Winkel, J.G.; Parren, P.W. Effector function activities of a panel of mutants of a broadly neutralizing antibody against human immunodeficiency virus type 1. J. Virol. 2001, 75, 12161-12168. [CrossRef] [PubMed]

64. Lo, M.; Kim, H.S.; Tong, R.K.; Bainbridge, T.W.; Vernes, J.M.; Zhang, Y.; Lin, Y.L.; Chung, S.; Dennis, M.S.; Zuchero, Y.J.; et al. Effector-attenuating Substitutions That Maintain Antibody Stability and Reduce Toxicity in Mice. J. Biol. Chem. 2017, 292, 3900-3908. [CrossRef] [PubMed]

65. Pincetic, A.; Bournazos, S.; DiLillo, D.J.; Maamary, J.; Wang, T.T.; Dahan, R.; Fiebiger, B.M.; Ravetch, J.V. Type I and type II Fc receptors regulate innate and adaptive immunity. Nat. Immunol. 2014, 15, 707-716. [CrossRef] [PubMed]

66. Bournazos, S.; Ravetch, J.V. Fcgamma Receptor Function and the Design of Vaccination Strategies. Immunity 2017, 47, 224-233. [CrossRef]

67. Overdijk, M.B.; Verploegen, S.; Ortiz Buijsse, A.; Vink, T.; Leusen, J.H.; Bleeker, W.K.; Parren, P.W. Crosstalk between human IgG isotypes and murine effector cells. J. Immunol. 2012, 189, 3430-3438. [CrossRef] 